Article

\title{
Organic-Inorganic Novel Green Cation Exchange Membranes for Direct Methanol Fuel Cells
}

\author{
Marwa H. Gouda ${ }^{1}$, Tamer M. Tamer ${ }^{1, *}$, Abdelaziz H. Konsowa ${ }^{2}$, Hassan A. Farag ${ }^{2}$ and \\ Mohamed S. Mohy Eldin 1,*
}

1 Polymer Materials Research Department, Advanced Technology and New Materials Research Institute (ATNMRI), City of Scientific Research and Technological Applications City (SRTA-City), Alexandria 21934, Egypt; marwagouda777@yahoo.com

2 Chemical Engineering Department, Faculty of Engineering, Alexandria University, Alexandria 21544, Egypt; akonsowa@alexu.edu.eg (A.H.K.); abualy2125@yahoo.com (H.A.F.)

* Correspondence: ttamer85@gmail.com (T.M.T.); mohyeldinmohamed@yahoo.com (M.S.M.E.)

Citation: Gouda, M.H.; Tamer, T.M.; Konsowa, A.H.; Farag, H.A.; Mohy Eldin, M.S. Organic-Inorganic Novel Green Cation Exchange Membranes for Direct Methanol Fuel Cells. Energies 2021, 14, 4686. https:// doi.org/10.3390/en14154686

Academic Editor:

George Avgouropoulos

Received: 5 May 2021

Accepted: 22 July 2021

Published: 2 August 2021

Publisher's Note: MDPI stays neutral with regard to jurisdictional claims in published maps and institutional affiliations.

Copyright: (c) 2021 by the authors. Licensee MDPI, Basel, Switzerland. This article is an open access article distributed under the terms and conditions of the Creative Commons Attribution (CC BY) license (https:// creativecommons.org/licenses/by/ $4.0 /)$.

\begin{abstract}
Commercializing direct methanol fuel cells (DMFC) demands cost-effective cation exchange membranes. Herein, a polymeric blend is prepared from low-cost and eco-friendly polymers (i.e., iota carrageenan (IC) and polyvinyl alcohol (PVA)). Zirconium phosphate $\left(\mathrm{ZrPO}_{4}\right)$ was prepared from the impregnation-calcination method and characterized by energy dispersive X-ray analysis (EDX map), X-ray diffraction analysis (XRD), Fourier transform infrared spectroscopy (FTIR), and transmission electron microscopy (TEM), then incorporated as a bonding and doping agent into the polymer blend with different concentrations. The new fabricated membranes were characterized by SEM, FTIR, thermogravimetric analysis (TGA), differential scanning calorimetry (DSC), and XRD. The results revealed that the membranes' physicochemical properties (oxidative stability, tensile strength) are enhanced with increasing doping addition, and they realized higher results than Nafion 117 because of increasing numbers of hydrogen bonds fabricated between the polymers and zirconium phosphate. Additionally, the methanol permeability was decreased in the membranes with increasing zirconium phosphate content. The optimum membrane with IC/SPVA/ $\mathrm{ZrPO}_{4}-7.5$ provided higher selectivity than Nafion 117. Therefore, it can be an effective cation exchange membrane for DMFCs applications.
\end{abstract}

Keywords: carrageenan; poly(vinyl alcohol); cation exchange membrane; direct methanol fuel cell; zirconium phosphate

\section{Introduction}

Fuel cells are utilized to directly transform the chemical reaction into electrical power. There are many kinds of fuel cells, such as methanol, ethanol, hydrogen, etc., and they achieve low pollution [1]. The DMFC, as a class of $\mathrm{H}$ exchange membrane fuel cells (PEMFC), is broadly used in home appliances, automobiles, aerospace, and other areas [2].

The membrane works as a separator between the methanol and oxidant and provides the chance for ions' conduction in the fuel cell. Nafion membranes are the most perfluorinated PEMs used in the DMFCs due to their good ionic conductivity and chemical and mechanical stability $[1,3]$, although their preparation requires high costs and complex steps $[4,5]$. Their substitution by inexpensive and green membranes is essential [6-8].

Scientists develop fuel cell membranes via sulfonation of polymers, blending [9], or adding a doping agent. Materials with functionalizing carbon and porous and functionalized inorganic materials have been used with membranes to replace Nafion membranes $[9,10]$. Non-perfluorinated polymers, such as poly(ether ether ketone), poly(styrene), and poly(benzimidazole), are the polymers commonly used for the preparation of novel alternative membranes [10-12]. Preparation of these non-degradable polymers demands a long time, toxic solvents, and high temperature, making the membranes' fabrication costly, complicated, and not green. From an economic and technological perspective, using green, 
inexpensive, and biodegradable polymers, such as IC and PVA, is an easier approach than modifying new complex polymers or developing the Nafion family membranes [10,13-15]. Furthermore, the cathode, the membrane, and the anode are the basic parts of a DMFC. Therefore, synthesizing low-cost and easy to manufacture membranes brings DMFCs closer to broad application.

Poly(vinyl alcohol) is eco-friendly, low cost, biodegradable, and has excellent adhesive, chemical stability, and film-forming properties $[10,16,17]$. Therefore, PVA is broadly used in industrial and medical applications. The semi-crystalline and rigid PVA structure limits its ionic conductivity and, consequently, its usage as a membrane in the fuel cells. Therefore, blending with doping agents or with other polymer electrolytes is essential to enhance its ionic conductivity $[10,14,16]$. Gouda et al. combined poly(vinyl alcohol) with IC through hydrogen bond interactions between the hydroxyl groups of the polymers for DMFCs. The results were an improvement in all the physicochemical properties $[18,19]$.

Iota carrageenan is a green polymer usually used to fabricate polymers' electrolyte membrane [20] because of its non-toxicity and chemical stability. Pasini Cabello et al. synthesized novel membranes by crosslinking alginate with carrageenan and noted increasing proton conductivity up to $30 \mathrm{mS} \mathrm{cm}^{-1}$ with increasing carrageenan percentage to $20 \% \mathrm{wt}$, and decreasing mechanical properties were also observed [21]. Therefore, the crosslinking step is critical in synthesizing the eco-friendly membranes to improve proton conductivity as well as mechanical stability, leading this research group to use two different crosslinkers.

Different researchers use a common technique for improving membranes' properties, which is incorporating doping materials into the polymeric membrane $[8,11,22,23]$.

$\mathrm{ZrPO}_{4}$ merging in polymers' matrix has been commonly used in fuel cells' application due to its chemical stability, large surface area, fuel crossover barrier, mechanical strength, low toxicity, and low cost [24-26]. Zirconium phosphate has hydrophilic phosphate groups which enhance water adsorption and increase proton conduction channels [27]. Upon merging of zirconium phosphate into polymers, hydrogen bonds will fabricate between polymer chains and zirconium phosphate, and these bonds will reinforce the membrane and compact it, as well as reducing the swelling and water uptake degree $[18,28,29]$. Further improvements in ionic conductivity of the membranes containing a high concentration of $\mathrm{ZrPO}_{4}$ are possible due to the fact that it holds more acidic (phosphate) groups in its structure, which consequently increase the proton conduction channels [27].

When Nafion is blended with zirconium phosphate, the membrane's methanol permeability is decreased and the mechanical properties are enhanced, and additionally, high-power density is achieved [30]. Alberti et al. achieved good conductivity at $90 \%$ humidity and $140{ }^{\circ} \mathrm{C}$ when Nafion was blended with $10 \mathrm{wt} \%$ zirconium phosphate [31].

This study aims to create effective and easy to manufacture membranes using biodegradable and inexpensive polymers, using water as the only solvent, to commercialize DMFCs. PVA was used as the essential polymer because of its film formation ability with iota carrageenan. Then, the polymeric blend was totally crosslinked and converted to sulfonated PVA at the same time using 4-sulphophthalic acid (SPA) as an ionic crosslinker and sulfonating agent and glutaraldehyde (GA) as a covalent crosslinker. Zirconium phosphate was prepared and incorporated as a bonding and doping agent into the polymeric blend to form new membranes, named IC/SPVA $/ \mathrm{ZrPO}_{4}$. The phosphate groups of zirconium phosphate, linked to the hydroxyl groups of PVA and IC through hydrogen bonds' formation, are expected to enhance the membranes' oxidative stability, hydrogen ions' conductivity, mechanical resistance, and obstruct the methanol crossover while decreasing the extreme water uptake, hence enhancing the DMFCs performance using such membranes.

\section{Materials and Methods}

Iota carrageenan (type V), 4-sulphophthalic acid (SPA) (99.9\%), zirconium nitrate (99\%), and PVA (medium MW, 99\% hydrolysis) were supplied by Sigma-Aldrich, (St. Louis, $\mathrm{MO}, \mathrm{USA})$. Glutaraldehyde (GA) $\left(25 \mathrm{wt} \%\right.$ in $\left.\mathrm{H}_{2} \mathrm{O}\right)$ was purchased from Alfa Aesar, Kandel, Germany. 


\subsection{Synthesis of $\mathrm{ZrPO}_{4}$}

Zirconium phosphate was synthesized by the impregnation-calcination method, where $6 \mathrm{~g}$ of zirconium nitrate was dissolved in a small amount of water with $4 \mathrm{~mL}$ of $\mathrm{H}_{3} \mathrm{PO}_{4}$. The solution was dried for $12 \mathrm{~h}$ at $120^{\circ} \mathrm{C}$. After that, the formed powder was transferred to a muffle for calcination at $500^{\circ} \mathrm{C}$ for $5 \mathrm{~h}$. Then, the dry particles were crushed by a ball mill for $10 \mathrm{~min}$ to obtain nano-size.

\subsection{Preparation of IC/SPVA/ZrPO $\mathrm{Z}_{4}$ Membranes}

First, a stock solution of $10 \%$ PVA and $2 \%$ IC was prepared by dissolving the definite amount of polymer in distilled water. Then, the proper amount of the two polymers was blended to reach the final ratio of IC:PVA (5:95 wt\%) with stirring to obtain a homogenous solution. After that, GA as a covalent crosslinker (5 g, $50 \mathrm{wt} \%)$ and SPA as an ionic crosslinker (5 g, $99.9 \mathrm{wt} \%$ ) were added to the blend solution with stirring. Additionally, SPA was used to sulfonate PVA to sulfonated polyvinyl alcohol (SPVA) [32-34]. Then, different concentrations of zirconium phosphate $(1,2.5,5,7.5 \mathrm{wt} \%)$ were incorporated in the polymer solution. The blended solution was poured into a glass Petri dish and dried at room temperature for the next $48 \mathrm{~h}$. Membranes were coded according to $\mathrm{ZrPO}_{4}$ content as IC/SPVA/ZrPO 4 -1, IC/SPVA/ZrPO 4 -2.5, IC/SPVA/ZrPO ${ }_{4}-5$, and IC/SPVA/ZrPO $\mathrm{ZP}_{4}-7.5$. Figure 1 illustrates the expected formula structure of the membrane.

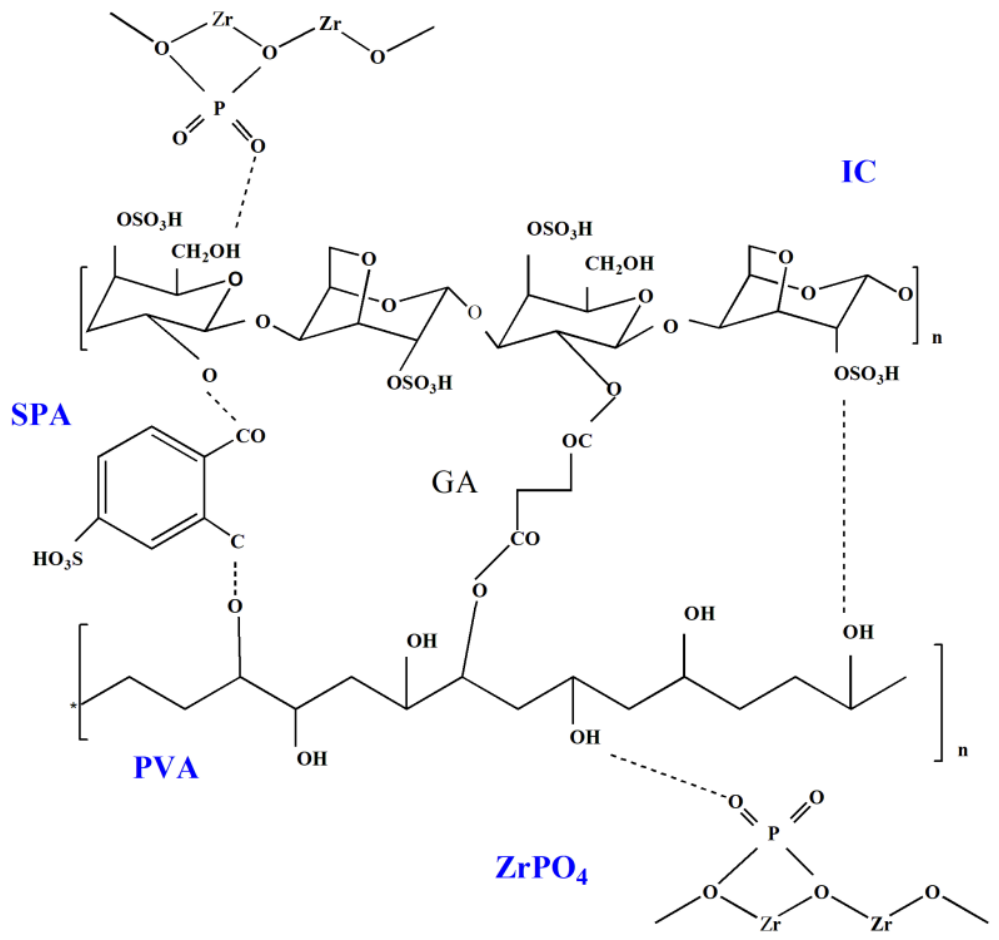

Figure 1. Possible interaction of the IC/SPVA/ $\mathrm{ZrPO}_{4}$ membrane.

\subsection{Characterization}

The characteristic function groups of zirconium phosphate and the membranes were verified by a Fourier transform infrared spectrophotometer (FTIR-8400 S, Shimadzu Corporation, Kyoto, Japan), while the crystal structures were proofed by an X-ray diffractometer (Schimadzu7000, Shimadzu Corporation, Kyoto, Japan). Thermal changes of IC $/ \mathrm{SPVA} / \mathrm{ZrPO}_{4}$ membranes were tracked using a thermogravimetric analyzer (TGA-50, Shimadzu Corporation, Kyoto, Japan), where temperature scanning ranged between 25 and $800^{\circ} \mathrm{C}$. Additionally, differential scanning calorimetry (DSC) (DSC-60, Shimadzu Corporation, Kyoto, Japan) at the range of $25-300^{\circ} \mathrm{C}$ was applied to show the thermal characteristics of membranes. The morphological structure of the IC/SPVA/ $\mathrm{ZrO}_{4}-7.5$ membrane was 
shown by scanning electron microscope (SEM) combined with energy-dispersive $\mathrm{X}$-ray (EDX) analysis (Joel Jsm 6360LA, JEOL Ltd., Tokyo, Japan). Visualization of the nano zirconium phosphate was performed by using transmission electron microscopy (TEM, JEM 2100 electron microscope, JEOL Ltd., Tokyo, Japan).

The contact angle between the sample surface and water drop was measured to test the hydrophilicity degree of the sample. Therefore, a contact angle analyzer (model 500-FI, Rame-Hart Instrument Co., Succasunna, NJ, USA) was applied. For measuring swelling ratio (SR) and water uptake (WU), a dry sample was cut, weighed, and its dimensions were measured. Then, the sample was placed in water for $24 \mathrm{~h}$, after which it was dried and weighed again. The SR and WU of the samples were calculated according to Equations (1) and (2):

$$
\begin{gathered}
\mathrm{SR}(\%)=\frac{L_{\mathrm{wet}}-L_{\mathrm{dry}}}{L_{\mathrm{dry}}} \times 100 \\
\mathrm{WU}(\%)=\frac{W_{\text {wet }}-W_{\text {dry }}}{W_{\text {dry }}} \times 100
\end{gathered}
$$

where $L_{\mathrm{dry}}$ and $L_{\text {wet }}$ are the length of dry and wet samples, while $W_{\mathrm{dry}}$ and $W_{\text {wet }}$ are the weight of dry and wet samples.

The ion exchange capacity (IEC) of the samples was measured using base-acid titration [35]. The weighted samples were placed in $50 \mathrm{~cm}^{3}$ of a $2 \mathrm{M} \mathrm{NaCl}$ solution for $48 \mathrm{~h}$, then the solutions were titrated with a $0.01 \mathrm{~N} \mathrm{NaOH}$ solution. IEC was calculated as follows:

$$
\operatorname{IEC}\left(\frac{\mathrm{m}_{\mathrm{eq}}}{\mathrm{gm}}\right)=\frac{\mathrm{V}_{\mathrm{NaOH}} \times \mathrm{C}_{\mathrm{NaOH}}}{W_{\mathrm{dry}}} \times 100
$$

where $\mathrm{V}_{\mathrm{NaOH}}, \mathrm{C}_{\mathrm{NaOH}}$, and $W_{\text {dry }}$ are the volume of sodium hydroxide consumed in titration, the concentration of sodium hydroxide solution, and the weight of the dry sample, respectively.

To determine the proton conductivity of the samples, resistance measurements were calculated by the impedance spectroscopy (EIS) technique using a PAR 273A potentiostat (Princeton Applied Research, Inc., Oak Ridge, TN, USA) coupled to a SI 1255 HF frequency response analyzer (FRA). The samples were placed in $1 \mathrm{M} \mathrm{H}_{2} \mathrm{SO}_{4}$ solution at room temperature for $24 \mathrm{~h}$ then thoroughly washed [1]. The membranes were placed between two stainless-steel electrodes at an open-circuit potential of $5 \mathrm{mV}$, with signal amplitude in the $100 \mathrm{~Hz}-100 \mathrm{kHz}$ frequency range. The high-frequency intercept on the Nyquist plot real axis shows the bulk membrane resistance, whereas the membranes' ionic conductivity was measured from estimated resistance according to Equation (4):

$$
\sigma=\frac{L}{R A}
$$

where $\sigma\left(\mathrm{S} \mathrm{cm}^{-1}\right)$ is the ionic conductivity of the sample, $R(\Omega)$ is the sample resistance, $A$ $\left(\mathrm{cm}^{2}\right)$ is the sample area, and $L(\mathrm{~cm})$ is the sample thickness.

The fuel permeability of the membrane was tested by diffusion cell according to the previously described method [18]. In brief, the membranes were fixed vertically between two tanks of $100 \mathrm{~mL}$. The first tank (A) was filled with $2 \mathrm{M}$ methanol, while the second tank (B) was filled with $\mathrm{H}_{2} \mathrm{O}$ [18]. Methanol diffuses from $\mathrm{A}$ to $\mathrm{B}$ across the membrane because of the concentration difference, and the methanol transferred to the tank (B) was measured by HPLC. The crossover of methanol from A to B as a function of time was determined by Equation (5):

$$
C_{\mathrm{B}}(t)=\frac{A}{V_{\mathrm{B}}} \frac{P}{L} C_{\mathrm{A}}\left(t-t_{0}\right)
$$

where $A\left(\mathrm{~cm}^{2}\right)$ is the area of permeability, $V_{\mathrm{B}}\left(\mathrm{cm}^{3}\right)$ is the receptor tank volume, $L(\mathrm{~cm})$ is the membrane thickness, $C_{\mathrm{B}}$ and $C_{\mathrm{A}}\left(\mathrm{mol} \mathrm{L}^{-1}\right)$ are the methanol concentrations in the tanks $\mathrm{B}$ and $\mathrm{A}$ respectively, the interval $\left(t-t_{0}\right)$ is the time of the methanol crossover, and $P$ is the 
methanol permeability of the membrane $\left(\mathrm{cm}^{2} \mathrm{~s}^{-1}\right)$. The membranes' selectivity (the ratio of the ionic conductivity to the methanol permeability) was measured because it provides us with an important indicator of fuel cell performance.

The oxidative stability of the prepared membrane was tested by measuring the weight loss of the membrane $\left(1.5 \times 1.5 \mathrm{~cm}^{2}\right)$ in Fenton's reagent $\left(3 \mathrm{wt} \% \mathrm{H}_{2} \mathrm{O}_{2}\right.$ containing $2 \mathrm{ppm}$ $\left.\mathrm{FeSO}_{4}\right)$ at $68^{\circ} \mathrm{C}$ for $24 \mathrm{~h} \mathrm{[18].}$

A tensile strength test, until membrane cutting, was performed for the dry membrane at room temperature by using Lloyd Instruments LR10k [32].

\section{Results and Discussion}

\subsection{Characterization of Nano Zirconium Phosphate and the Membranes}

Figure 2a illustrates the characteristic peaks of $\mathrm{ZrPO}_{4}$, showing a broad peak around $3300 \mathrm{~cm}^{-1}$ and a peak at around $1630 \mathrm{~cm}^{-1}$ that referred to the adsorbed $\mathrm{H}_{2} \mathrm{O}$, and a peak around the $500 \mathrm{~cm}^{-1} \mathrm{Zr}-\mathrm{O}$ band. IR bands of the $\mathrm{PO}_{4}{ }^{3-}$ group were in the region of 1000-1200 $\mathrm{cm}^{-1}$ [36]. On the other hand, for the membranes in Figure $2 b$, the bands around $3250 \mathrm{~cm}^{-1}$ are characteristic of hydroxyl groups of IC and PVA, and the bands at $1650 \mathrm{~cm}^{-1}$ refer to the $\mathrm{O}-\mathrm{H}$ bonds from $\mathrm{H}_{2} \mathrm{O}$ that are more adsorbed as the concentration of $\mathrm{ZrPO}_{4}$ increases because of its hydrophilic quality. The peak at $830 \mathrm{~cm}^{-1}$ is attributed to the $\mathrm{SO}_{4}$ group of IC. Bands at $2840 \mathrm{~cm}^{-1}$ refer to the $\mathrm{C}-\mathrm{H}$ bonds of polymers. The weak peaks at 1700 and $1750 \mathrm{~cm}^{-1}$ are attributed to the $\mathrm{C}=\mathrm{O}$ and $\mathrm{C}-\mathrm{H}$ bonds of sulfophithalic acid respectively, proof that the crosslinking step is realized. The bands at $1100 \mathrm{~cm}^{-1}$ are attributed to the $\mathrm{SO}_{4}$ group of SPA.

(a)

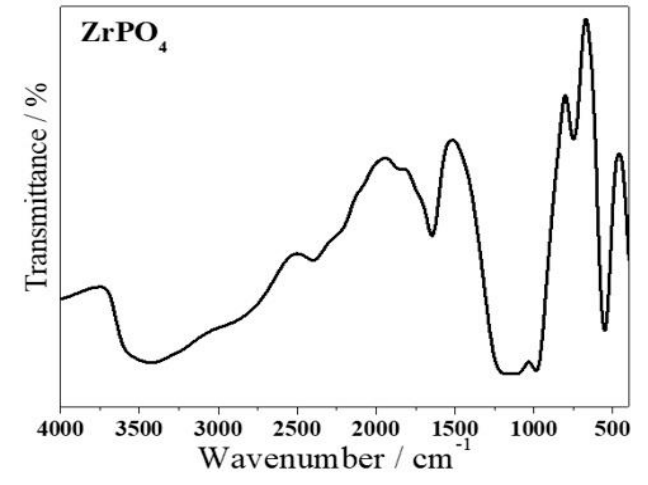

(b)

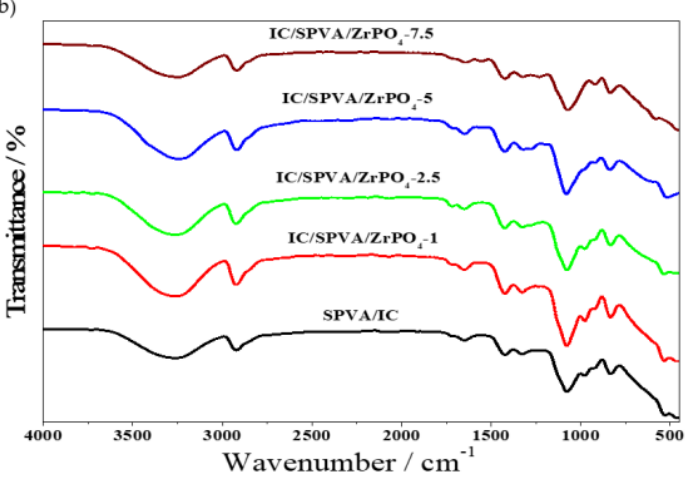

Figure 2. FTIR of (a) zirconium phosphate and (b) IC/SPVA $/ \mathrm{ZrOO}_{4}$ membranes.

Figure 3 presents the XRD for zirconium phosphate and IC/SPVA/Z $\mathrm{rPO}_{4}-7.5 \mathrm{mem}$ branes. The figure presents the amorphous structure for the fabricated IC/SPVA $/ \mathrm{ZrPO}_{4}$ 7.5 membrane, which is an indication of the membrane's ability for good conduction of ions [37], while the characteristic peaks of $\mathrm{ZrPO}_{4}$ appeared at a $2 \theta$ angle of 23, 21, 35, and 25 degrees [37,38].

Membrane morphology plays an essential role in performance and applications. Figure 4 displays SEM and TEM images of the developed undoped membrane and the IC/SPVA/Z $\mathrm{rPO}_{4}-7.5$ membrane. Figure 4a displays the smooth surface of the undoped membrane without defects; however, in Figure $4 \mathrm{~b}$, a good dispersion of $\mathrm{ZrPO}_{4}$ is shown for the doped membrane without distinct agglomeration, while in Figure $4 \mathrm{c}$, a compact structure of the cross-section is presented. In Figure $4 \mathrm{~d}$, the nano-size of $\mathrm{ZrPO}_{4}$ was proven by TEM image and confirmed by the frequency distribution, and Figure 4e shows EDX mapping of zirconium phosphate, proof of $\mathrm{P}, \mathrm{Zr}$, and $\mathrm{O}$ elements' existence and distribution. 


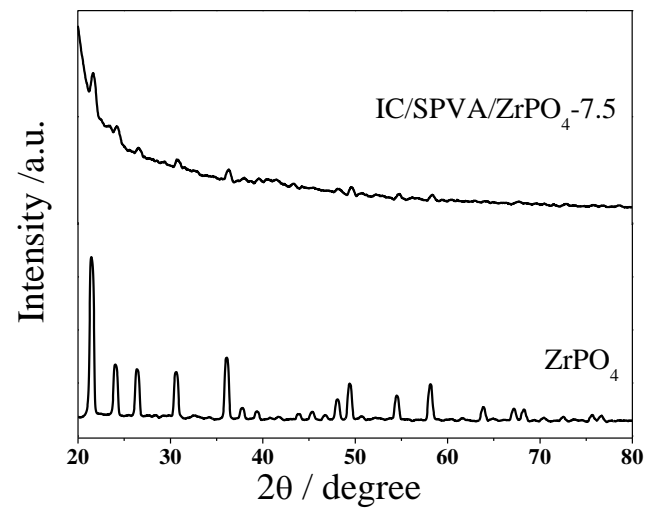

Figure 3. $\mathrm{XRD}$ of $\mathrm{ZrPO}_{4}$ powder and $\mathrm{IC} / \mathrm{SPVA} / \mathrm{ZrPO}_{4}-7.5$ membranes.
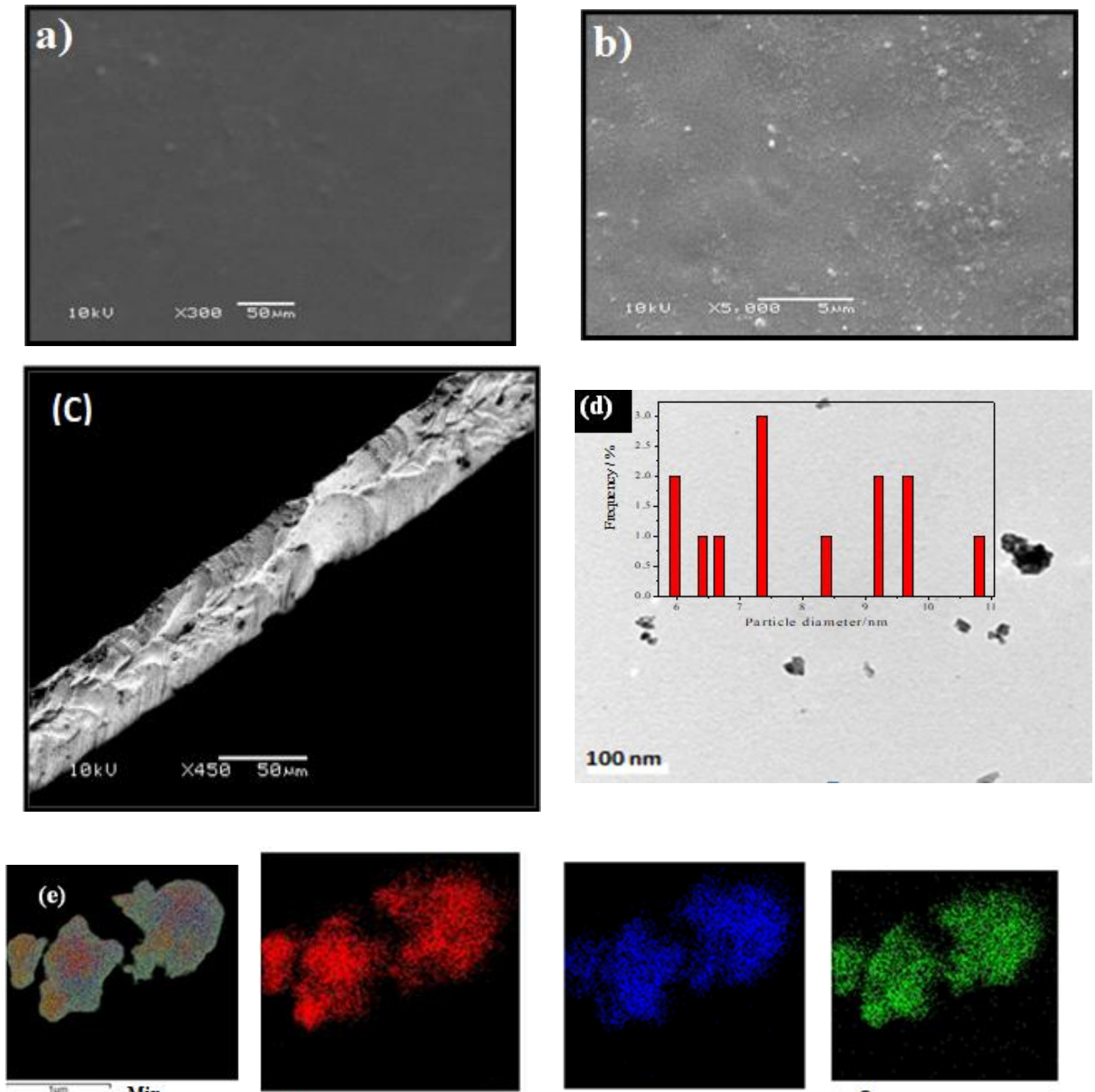

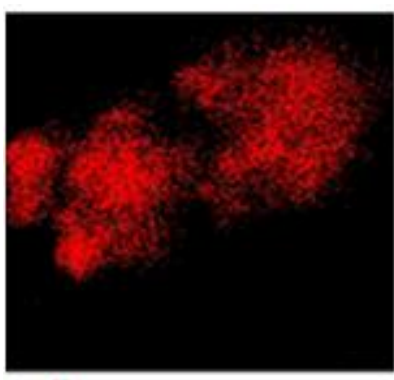

$\mathrm{Zr}$

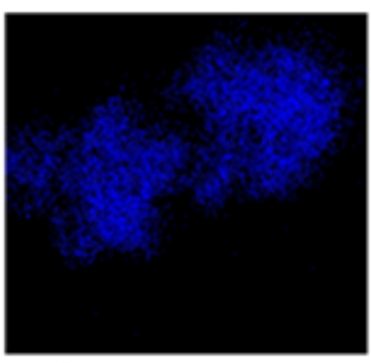

P

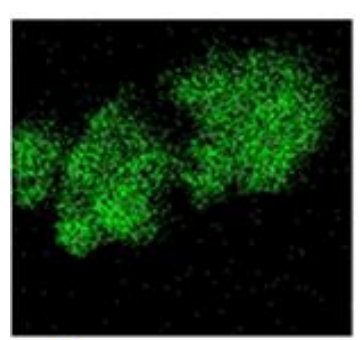

o

Figure 4. SEM images of (a) undoped surface, (b) IC/PVA/ZrPO 4 -7.5 surface, (c) cross-section of IC/PVA/ZrPO 4 -7.5, (d) TEM image of nano zirconium phosphate, and (e) EDX mapping of nano zirconium phosphate. 


\subsection{Mechanical and Thermal Analysis}

Zirconium phosphate enhances the mechanical properties of the membranes $[31,39,40]$. As shown in Table 1, by increasing zirconium phosphate insertion in the polymeric structure, the mechanical tensile strength of the membranes was increased due to improving the compatibility of the membrane components as a result of enhancing the bonding between the polymers and zirconium phosphate, through ionic, hydrogen, and covalent bonds, which increased the interfacial adhesion in the membranes when compared to the membrane without doping.

Table 1. Physicochemical properties of the membranes and Nafion [1,31].

\begin{tabular}{|c|c|c|c|c|c|c|}
\hline Membrane & $\begin{array}{l}\text { Thickness } \\
\quad(\mu \mathrm{m})\end{array}$ & WU * $(\%)$ & $S R *(\%)$ & $\begin{array}{c}\text { Contact Angle } \\
\left({ }^{\circ}\right)\end{array}$ & $\begin{array}{c}\text { Tensile } \\
\text { Strength (MPa) }\end{array}$ & $\begin{array}{c}\text { Oxidative } \\
\text { Stability (RW, \%) * }\end{array}$ \\
\hline IC/SPVA & 110 & $>100 \pm 0.5$ & $90 \pm 0.4$ & $45.36 \pm 2$ & $12.2 \pm 0.5$ & $81 \pm 2$ \\
\hline IC/SPVA/ZrPO $4-1$ & 150 & $49 \pm 0.4$ & $45 \pm 0.4$ & $48.23 \pm 1.5$ & $22.9 \pm 1$ & $90 \pm 1.5$ \\
\hline $\mathrm{IC} / \mathrm{SPVA} / \mathrm{ZrPO}_{4}-2.5$ & 170 & $20 \pm 0.2$ & $15 \pm 0.3$ & $50.36 \pm 1.5$ & $29.5 \pm 1$ & $98 \pm 1.5$ \\
\hline $\mathrm{IC} / \mathrm{SPVA} / \mathrm{ZrPO}_{4}-5$ & 174 & $19 \pm 0.1$ & $16 \pm 0.2$ & $50.31 \pm 1$ & $35.3 \pm 1.5$ & $99 \pm 0.5$ \\
\hline $\mathrm{IC} / \mathrm{SPVA} / \mathrm{ZrPO}_{4}-7.5$ & 180 & $20 \pm 0.05$ & $16 \pm 0.1$ & $49.50 \pm 1$ & $39.1 \pm 2$ & $98.5 \pm 0.5$ \\
\hline Nafion 117 & 183 & 15 & 8 & 102 & 25 & 92 \\
\hline
\end{tabular}

* Swelling ratio $(\mathrm{SR} \%)$ and water uptake (WU\%) of the membranes after immersion for a day in water. * The retained weight of the composite membrane (RW) after placing in Fenton's reagent for $24 \mathrm{~h}$.

TGA of the membranes without and with zirconium phosphate are illustrated in Figure 5a. The first weight loss at $\sim 150^{\circ} \mathrm{C}(\sim 10 \%)$ referred to the moisture evaporation in the samples $[14,41]$. The second degradation of the membranes happened at the range of $\sim(150-$ $320)^{\circ} \mathrm{C}$, and referred to the functional groups' decomposition [42,43]. The last weight loss was noticed by a remarkable degradation from $\sim 320$ to $500^{\circ} \mathrm{C}$, which was attributed to the polymer chains' dissolution [44], that started at $230^{\circ} \mathrm{C}$ for the membrane without doping, while for the membrane with $7.5 \mathrm{wt} \% \mathrm{ZrPO}_{4}$, it started at $320^{\circ} \mathrm{C}$ with less degradation. This figure clarifies that the doping insertion improves the thermal stability of the membranes by increasing covalent, hydrogen, and ionic bonding in the nanocomposite membranes. For DSC, as shown in Figure 5b, the appearance of one endothermic peak provides clear evidence of complete miscibility in the composite structure, and the disappearance of this peak in zirconium phosphate ( 5 and $7.5 \mathrm{wt} \%$ ) referred to the formation of many more hydrogen bonds between $\mathrm{ZrPO}_{4}$ and the polymer chains [18]. The melting temperature of the composites decreased with the increase of $\mathrm{ZrPO}_{4}$ content. This was attributed to the hydrogen bonds, which could partially reduce the composites' crystallinity, consequently reducing the melting point and enhancing the ionic conductivity [18].

The contact angles of the membranes are shown in Table 1. The sample surface is hydrophobic when the angle is $\geq 90^{\circ}$ and hydrophilic when it is $<90^{\circ}$. The membrane has a less hydrophilic property with bigger thickness due to increasing the nanomaterials' content $[34,45]$. The hydrophilic quality of zirconium phosphate predominated with increasing its amount in the structure, and therefore a reduction in contact angles was noted. With increasing the content of zirconium phosphate in the membranes from $1 \%$ to $2.5 \%$, the SR and WU of the membranes were reduced, which is essential for avoiding water overload [46]. Increasing the dopant in the structure leads to increasing the matrix compactness, which will limit water overload in the membrane channels when compared to the membrane without a dopant $[47,48]$. When the content of zirconium phosphate increased from $5 \%$ to $7.5 \%$, a slight increase in WU was noted, and this behavior refers to the hygroscopic quality of zirconium phosphate that became predominate at high amounts, but this increase was within acceptable and reasonable limits. 
(a)

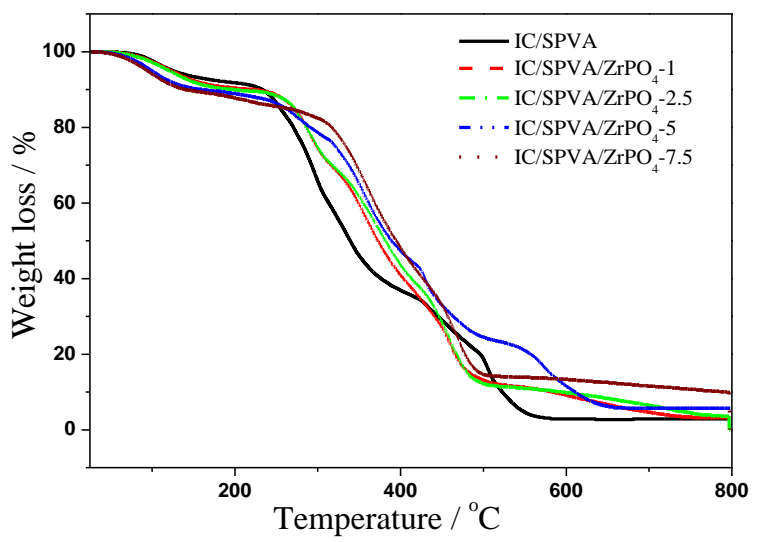

(b)

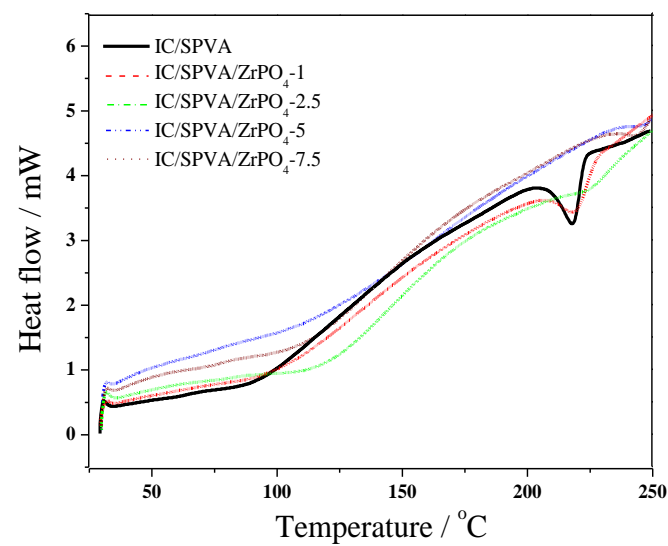

Figure 5. (a) TGA and (b) DSC curves of $\mathrm{ZrPO}_{4}$ nanocomposite membranes.

\subsection{Oxidative Stability}

Fenton's reagent test was used to evaluate the chemical stability of the membranes, as shown in Table 1 . The membrane without doping realized the lowest oxidative stability, while insertion of zirconium phosphate as a dopant enhanced the membranes' resistance to $\mathrm{OH}$ radicals' attack. IC/SPVA $/ \mathrm{ZrPO}_{4}-5$ and IC/SPVA $/ \mathrm{ZrPO}_{4}-7.5$ membranes were the most stable fabricated membranes, for which the retained weights were about $99 \%$ and $98.5 \%$ respectively, and therefore, we can deduce that the addition of a doping agent, such as $\mathrm{ZrPO}_{4}$, increases the chemical stability of the polymeric membranes [49].

\subsection{Methanol Crossover, Ionic Conductivity, IEC, and Selectivity}

The IEC results are shown in Table 2, and we can see that as the content of zirconium phosphate increases in the membrane structure, the IEC increases, because the membrane structure holds more acidic groups from zirconium phosphate. The $\mathrm{H}+$ exchangeable sites of zirconium phosphate increase the negative charges in the membrane, which is related to proton conduction improvement [50].

Table 2. Methanol permeability, ion exchange capacity (IEC), selectivity, and ionic conductivity of the prepared membranes, previous study, and Nafion 117.

\begin{tabular}{|c|c|c|c|c|c|}
\hline Membrane & $\begin{array}{c}\text { Ionic } \\
\text { Conductivity } \\
\left(\mathrm{mS} \mathrm{cm}^{-1}\right)\end{array}$ & IEC (meq $\left.\mathbf{g}^{-1}\right)$ & $\begin{array}{c}\text { Methanol } \\
\text { Permeability } \\
\left(10^{-7} \mathrm{~cm}^{2} \mathrm{~s}^{-1}\right)\end{array}$ & $\begin{array}{c}\text { Selectivity } \\
\left(10^{5} \mathrm{~S} \mathrm{~cm}^{-3} \mathrm{~s}\right)\end{array}$ & Reference \\
\hline IC/SPVA & $10.1 \pm 0.04$ & $0.20 \pm 0.02$ & 3.9 & 0.25 & This study \\
\hline $\mathrm{IC} / \mathrm{SPVA} / \mathrm{ZrPO}_{4}-1$ & $15.7 \pm 0.04$ & $0.20 \pm 0.02$ & 3.5 & 0.45 & This study \\
\hline $\mathrm{IC} / \mathrm{SPVA} / \mathrm{ZrPO}_{4}-2.5$ & $17.3 \pm 0.04$ & $0.25 \pm 0.02$ & 3.0 & 0.57 & This study \\
\hline $\mathrm{IC} / \mathrm{SPVA} / \mathrm{ZrPO}_{4}-5$ & $25.5 \pm 0.02$ & $0.35 \pm 0.02$ & 2.7 & 0.94 & This study \\
\hline $\mathrm{IC} / \mathrm{SPVA} / \mathrm{ZrPO}_{4}-7.5$ & $25.5 \pm 0.02$ & $0.40 \pm 0.02$ & 2.5 & 1.02 & This study \\
\hline Nafion 117 & 34.0 & 0.89 & 14.1 & 0.24 & [1] \\
\hline $\mathrm{PVA} / \mathrm{ZrPO}_{4}$ & $10-30$ & $3-3.2$ & $2-3.5$ & - & [51] \\
\hline
\end{tabular}

Good proton conductivity of IC/SPVA $/ \mathrm{ZrPO}_{4}-7.5$ was $25.5 \mathrm{mS} \mathrm{cm}{ }^{-1}$ when compared to IC/SPVA (10.1 mS cm$\left.~^{-1}\right)$, but was still lower than Nafion $117\left(45 \mathrm{mS} \mathrm{cm}^{-1}\right)$. It can be seen that the proton conductivity of the membranes with 7.5 and $5 \% \mathrm{wt}$ of zirconium phosphate were equal $\left(25.5 \mathrm{mS} \mathrm{cm}^{-1}\right)$ because of agglomeration, which may occur at high contents of dopant. Regarding the methanol permeability of membranes, we can note that the insertion of zirconium phosphate in the polymers' structure reduced the fuel crossover. 
As shown in Table 2, the permeability of the undoped sample was $3.9 \times 10^{-7} \mathrm{~cm}^{2} \mathrm{~s}^{-1}$, and upon insertion of zirconium phosphate in the polymeric structure, the permeability reduced to $2.5 \times 10^{-7} \mathrm{~cm}^{2} \mathrm{~s}^{-1}$ for the IC/SPVA/ $\mathrm{ZPO}_{4}-7.5$. This reduction may be attributed to the ability of the dopant in narrowing the structure channels, which reduces the WU, and thus the methanol permeability will decrease [18,32,34,51]. The highest selectivity noticed for IC/SPVA/Z $\mathrm{rPO}_{4}-7.5$ was $1.02 \times 10^{5} \mathrm{~S} \mathrm{~cm}^{-3} \mathrm{~s}$, compared with IC/SPVA that has a selectivity of $0.25 \times 10^{5} \mathrm{~S} \mathrm{~cm}^{-3} \mathrm{~s}$, which signals the suitability of the prepared membrane to be applied in DMFCs [19].

\section{Conclusions}

A cheap composite membrane was fabricated by simple casting using eco-environmental and available polymers. The study revealed that the incorporation of $\mathrm{ZrPO}_{4}$ as a doping agent into the polymeric blend improved the membranes' properties, such as mechanical and oxidative stability, reduced the water overload, and methanol crossover limiting was enhanced, especially in the composite membranes with $5 \%$ and $7.5 \%$ of $\mathrm{ZrPO}_{4}$, which show oxidative stability, methanol permeability, mechanical properties, and selectivity much better than Nafion. In conclusion, the fabricated membranes with the optimum properties (IC/SPVA/ $\mathrm{ZrO}_{4}-7.5$ and IC/SPVA $/ \mathrm{ZrPO}_{4}-5$ ) can be effective proton exchange membrane towards the development of inexpensive and green DMFCs.

Author Contributions: Formal analysis, M.H.G.; Investigation, M.H.G.; Methodology, M.H.G.; Software, M.H.G.; Supervision, A.H.K., H.A.F. and M.S.M.E.; Writing—original draft, M.H.G. and T.M.T. The manuscript was written through the contributions of all authors. All authors have read and agreed to the published version of the manuscript.

Funding: This research received no external funding.

Data Availability Statement: Exclude this statement.

Acknowledgments: The authors affiliated of (SRTA-City) would like to express their grateful thanks to the City of Scientific Research and Technological Applications (SRTA-City) for its support in implementing preparation and characterization and evaluation.

Conflicts of Interest: The authors declare no conflict of interest.

\section{References}

1. Yuan, C.; Wang, Y. Synthesis and characterization of a crosslinked membrane based on sulfonated poly (aryl ether sulfone) and sulfonated polyvinyl alcohol applied in direct methanol fuel cells. J. Polym. Res. 2020, 27, 329. [CrossRef]

2. Beydaghi, H.; Javanbakht, M.; Salarizadeh, P.; Bagheri, A.; Amoozadeh, A. Novel proton exchange membrane nanocomposites based on sulfonated tungsten trioxide for application in direct methanol fuel cells. Polymer 2017, 119, 253-262. [CrossRef]

3. Zhiwei, W.; Hao, Z.; Qiang, C.; Sumei, Z.; Feng, Y.; Jian, K.; Jinyao, C.; Ya, C.; Ming, X. Preparation and characterization of PVA proton exchange membranes containing phosphonic acid groups for direct methanol fuel cell applications. J. Polym. Res. 2019, 26, 200. [CrossRef]

4. Pandey, R.P.; Shukla, G.; Manohar, M.; Shahi, V.K. Graphene oxide based nanohybrid proton exchange membranes for fuel cell applications: An overview. Adv. Colloid Interface Sci. 2017, 240, 15-30. [CrossRef]

5. Ye, Y.S.; Rick, J.; Hwang, B.J. Water soluble polymers as proton exchange membranes for fuel cells. Polymers 2012, 4, 913-963. [CrossRef]

6. Ma, J.; Choudhury, N.A.; Sahai, Y. A comprehensive review of direct borohydride fuel cells. Renew. Sustain. Energy Rev. 2020, 14, 183-199. [CrossRef]

7. Merino-Jiménez, I.; León, C.P.; Shah, A.A.; Walsh, F.C. Developments in direct borohydride fuel cells and remaining challenges. J. Power Sources 2012, 219, 339-357. [CrossRef]

8. Gouda, M.H.; Elnouby, M.; Aziz, A.N.; Youssef, M.E.; Santos, D.M.F.; Elessawy, N.A. Green and Low-Cost Membrane Electrode Assembly for Proton Exchange Membrane Fuel Cells: Effect of Double-Layer Electrodes and Gas Diffusion Layer. Front. Mater. 2020, 6. [CrossRef]

9. Mohy Eldin, M.S.; Hashem, A.E.; Tamer, T.M.; Omer, A.M.; Yossuf, M.E.; Sabet, M.M. Development of cross linked chitosan/alginate polyelectrolyte proton exchanger membranes for fuel cell applications. Int. J. Electrochem. Sci. 2017, 12, 3840-3858. [CrossRef]

10. Tamer, T.M.; Omer, A.M.; Sabet, M.M.; Youssef, M.E.; Hashem, A.I.; Mohy Eldin, M.S. Development of polyelectrolyte sulfonated chitosan-alginate as an alternative methanol fuel cell membrane. Desalination Water Treat. 2021, 227, $132-148$. 
11. Pourzare, K.; Mansourpanah, Y.; Farhadi, S. Advanced nanocomposite membranes for fuel cell applications: A comprehensive review. Biofuel Res. J. 2016, 12, 496-513. [CrossRef]

12. Bakangura, E.; Wu, L.; Ge, L.; Yang, Z.; Xu, T. Mixed matrix proton exchange membranes for fuel cells: State of the art and perspectives. Prog. Polym. Sci. 2016, 57, 103-152. [CrossRef]

13. Wei, Q.; Zhang, Y.; Wang, Y.; Chai, W.; Yang, M. Measurement and modeling of the effect of composition ratios on the properties of poly(vinyl alcohol)/poly(vinyl pyrrolidone) membranes. Mater. Des. 2016, 103, 249-258. [CrossRef]

14. Maarouf, S.; Tazi, B.; Guenoun, F. Preparation and characterization of new composite membranes containing polyvinylpyrrolidone, polyvinyl alcohol, sulfosuccinic acid, silicotungstic acid and silica for direct methanol fuel cell applications. J. Mater. Environ. Sci. 2017, 8, 2870-2876.

15. Pintauro, P. Perspectives on Membranes and Separators for Electrochemical Energy Conversion and Storage Devices. Polym. Rev. 2015, 55, 201-217. [CrossRef]

16. Chen, J.; Li, Y.; Zhang, Y.; Zhu, Y. Preparation and characterization of graphene oxide reinforced PVA film with boric acid as crosslinker. J. Appl. Polym. Sci. 2015, 132, 1-8. [CrossRef]

17. Ye, Y.S.; Cheng, M.Y.; Xie, X.L.; Rick, J.; Huang, Y.J.; Chang, F.C.; Hwang, B.J. Alkali doped polyvinyl alcohol/graphene electrolyte for direct methanol alkaline fuel cells. J. Power Sources 2013, 239, 424-432. [CrossRef]

18. Gouda, M.H.; Konsowa, A.H.; Farag, H.A.; Elessawy, N.A.; Tamer, T.M.; MohyEldin, M.S. Novel nanocomposite membranes based on cross-linked eco-friendly polymers doped with sulfated titania nanotubes for direct methanol fuel cell application. Nanomater. Nanotechnol. 2020, 10, 1-9. [CrossRef]

19. MohyEldin, M.S.; Farag, H.A.; Tamer, T.M.; Konsowa, A.H.; Gouda, M.H. Development of novel iota carrageenan-g-polyvinyl alcohol polyelectrolyte membranes for direct methanol fuel cell application. Polym. Bull. 2020, 77, 4895-4916. [CrossRef]

20. Karthikeyan, S.; Selvasekarapandian, S.; Premalatha, M.; Monisha, S.; Boopathi, G.; Aristatil, G.; Arun, A.; Madeswaran, S. Proton-conducting I-Carrageenan-based biopolymer electrolyte for fuel cell application. Ionics 2016, 23, 2775-2780. [CrossRef]

21. PasiniCabello, S.D.; Mollá, S.; Ochoa, N.A.; Marchese, J.; Giménez, E.; Compañ, V. New bio-polymeric membranes composed of alginate-carrageenan to be applied as polymer electrolyte membranes for DMFC. J. Power Sources 2014, 265, 345-355. [CrossRef]

22. Sedesheva, Y.S.; Ivanov, V.S.; Wozniak, A.I.; Yegorov, A.S. Proton-exchange membranes based on sulfonated polymers. Orient. J. Chem. 2016, 32, 2283-2296. [CrossRef]

23. Awang, N.; Ismail, A.F.; Jaafar, J.; Matsuura, T.; Junoh, H.; Othman, M.H.D.; Rahman, M.A. Functionalization of polymeric materials as a high-performance membrane for direct methanol fuel cell: A review. React. Funct. Polym. 2015, 86, $248-258$. [CrossRef]

24. Vaivars, G.; Mokrani, T.; Hendricks, N.; Linkov, V. Inorganic membranes based on zirconium phosphate for fuel cells. J. Solid State Electrochem. 2004, 8, 882-885. [CrossRef]

25. Yang, C.; Srinivasan, S.; Bocarsly, A.B.; Tulyani, S.; Benziger, J.B. Performance of Nafion/zirconium phosphate composite membranes in PEM fuel cells. J. Membr. Sci. 2004, 237, 145-161. [CrossRef]

26. Bauer, F.; Willert-Porada, M. Characterisation of zirconium and titanium phosphates and direct methanol fuel cell (DMFC) performance of functionally graded Nafion (R) composite membranes prepared out of them. J. Power Sources 2005, 145, 101-107. [CrossRef]

27. Rahaman, S.K.J.; Mukherjee, M.; Sarkhel, G. Effect of Zirconium Phosphate on Structural, Thermal, and Electrical Properties of Polyether Sulfone (PES) Membrane. Int. J. Polym. Mater. 2012, 61, 655-668. [CrossRef]

28. Deshmukh, K.; Ahamed, M.B.; Sadasivuni, K.K.; Ponnamma, D.; Deshmukh, R.R.; Pasha, S.K.K.; AlMaadeed, M.A.; Chidambaram, K. Graphene oxide reinforced polyvinyl alcohol/polyethylene glycol blend composites as high-performance dielectric material. J. Polym. Res. 2016, 23, 159. [CrossRef]

29. Li, C.; Xiao, L.; Jiang, Z.; Tian, X.; Luo, L.; Liu, W.; Xu, Z.L.; Yang, H.; Jiang, Z.J. Sulfonic acid functionalized graphene oxide paper sandwiched in sulfonated poly(ether ether ketone): A proton exchange membrane with high performance for semi-passive direct methanol fuel cells. Int. J. Hydrogen Energy 2017, 42, 16731-16740. [CrossRef]

30. Sigwadi, R.; Dhlamini, M.S.; Mokrani, T.; Nemavhola, F.; Nonjola, P.F.; Msomi, P.F. The proton conductivity and mechanical properties of Nafion ${ }^{\circledR} / \mathrm{ZrP}$ nanocomposite membrane. Heliyon 2019, 5, e02240. [CrossRef]

31. Alberti, G.; Casciola, M.; Capitani, D.; Donnadio, A.; Narducci, R.; Pica, M.; Sganappa, M. Novel Nafion-zirconium phosphate nanocomposite membranes with enhanced stability of proton conductivity at medium temperature and high relative humidity. Electrochim. Acta 2007, 52, 8125-8132. [CrossRef]

32. Gouda, M.H.; Gouveia, W.; El Essawy, N.A.; Šljukić, B.; Nassr, A.A.A.; Santos, D.M.F. Simple design of PVA-based blend doped with $\mathrm{SO} 4(\mathrm{PO} 4)$-functionalised TiO2as an effective membrane for direct borohydride fuel cells. Int. J. Hydrogen Energy 2020, 45, 15226-15238. [CrossRef]

33. Gouda, M.H.; Gouveia, W.; Afonso, M.L.; Šljukić, B.; Elessawy, N.A.; Santos, D.M.F. Novel Ternary Polymer Blend Membranes Doped with SO4/PO4-TiO2 for Low Temperature Fuel Cells. In Proceedings of the 5th World Congress on Mechanical, Chemical, and Material Engineering (MCM'19), Paper No. ICCPE 106, Lisbon, Portugal, 15-17 August 2019. [CrossRef]

34. Gouda, M.H.; Gouveia, W.; Afonso, M.L.; Šljukić, B.; El Essawy, N.A.; Nassr, A.A.A.; Santos, D.M.F. Poly(vinyl alcohol)-based crosslinked ternary polymer blend doped with sulfonated graphene oxide as a sustainable composite membrane for direct borohydride fuel cells. J. Power Sources 2019, 432, 92-101. [CrossRef] 
35. Gouda, M.H.; Elessawy, N.A.; Santos, D.M.F. Synthesis and Characterization of Novel Green Hybrid Nanocomposites for Application as Proton Exchange Membranes in Direct Borohydride Fuel Cells. Energies 2020, 13, 1180. [CrossRef]

36. Han, L.; Chen, Q.; Chen, H.; Yu, S.; Xiao, L.; Ye, Z. Synthesis and Performance of Functionalized $\alpha$-Zirconium Phosphate Modified with Octadecyl Isocyanate. J. Nanomater. 2018, 2018. [CrossRef]

37. Yu, X.; Qiang, L. Preparation for graphite materials and study on electrochemical degradation of phenol by graphite cathodes. Adv. Mater. Phys. Chem. 2012, 2, 63-68. [CrossRef]

38. Bestaoui, N.; Spurr, N.A.; Clearfield, A. Intercalation of polyetheramines into $\alpha$-zirconium phosphate. J. Mater. Chem. 2006, 16, 759-764. [CrossRef]

39. Pica, M.; Donnadio, A.; Casciola, M.; Cojocaru, P.; Merlob, L. Short side chain perfluorosulfonic acid membranes and their composites with nanosized zirconium phosphate: Hydration, mechanical properties and proton conductivity. J. Mater. Chem. 2012, 22, 24902. [CrossRef]

40. Casciola, M.; Capitani, D.; Comite, A.; Donnadio, A.; Frittella, V.; Pica, M.; Sganappa, M.; Varzi, A. Nafion-Zirconium Phosphate Nanocomposite Membranes with High Filler Loadings: Conductivity and Mechanical Properties. Fuel Cells 2008, 3-4, 217-224. [CrossRef]

41. Kowsari, E.; Zare, A.; Ansari, V. Phosphoric acid-doped ionic liquid-functionalized graphene oxide/sulfonated polyimide composites as proton exchange membrane. Int. J. Hydrogen Energy 2015, 40, 13964-13978. [CrossRef]

42. Bayer, T.; Cunning, B.V.; Selyanchyn, R.; Daio, T.; Nishihara, M.; Fujikawa, S.; Sasaki, K.; Lyth, S.M. Alkaline anion exchange membranes based on KOH-treated multilayer graphene oxide. J. Membr. Sci. 2016, 508, 51-61. [CrossRef]

43. Pandey, R.; Shahi, V. Sulphonated imidized graphene oxide (SIGO) based polymer electrolyte membrane for improved water retention, stability and proton conductivity. J. Power Sources 2015, 299, 104-113. [CrossRef]

44. Gomaa, M.M.; Hugenschmidt, C.; Dickmann, M.; Abdel-Hady, E.E.; Mohamed, H.F.M.; Abdel-Hamed, M.O. Crosslinked PVA/SSA proton exchange membranes: Correlation between physiochemical properties and free volume determined by positron annihilation spectroscopy. Phys. Chem. Chem. Phys. 2018, 20, 28287-28299. [CrossRef] [PubMed]

45. Shirdast, A.; Sharif, A.; Abdollahi, M. Effect of the incorporation of sulfonated chitosan/sulfonated graphene oxide on the proton conductivity of chitosan membranes. J. Power Sources 2016, 306, 541-551. [CrossRef]

46. Beydaghi, H.; Javanbakht, M.; Kowsari, E. Synthesis and Characterization of Poly(vinyl alcohol)/Sulfonated Graphene Oxide Nanocomposite Membranes for Use in Proton Exchange Membrane Fuel Cells (PEMFCs). Ind. Eng. Chem. Res. 2014, 53, 16621-16632. [CrossRef]

47. Cheng, T.; Feng, M.; Huang, Y.; Liu, X. SGO/SPEN-based highly selective polymer electrolyte membranes for direct methanol fuel cells. Ionics 2017, 23, 2143-2152. [CrossRef]

48. Luo, T.; Xu, H.; Li, Z.; Gao, S.; Fang, Z.; Zhang, Z.; Wang, F.; Ma, B.; Zhu, C. Novel proton conducting membranes based on copolymers containing hydroxylated poly(ether ether ketone) and sulfonated polystyrenes. J. Appl. Polym. Sci. 2017, 134, 1-8. [CrossRef]

49. Ozdena, A.; Ercelik, M.; Devrim, Y.; Colpan, C.O.; Hamdullahpur, F. Evaluation of sulfonated polysulfone/zirconium hydrogen phosphate composite membranes for direct methanol fuel cells. Electrochim. Acta 2017, 256, 196-210. [CrossRef]

50. Li, M.; Scott, K. A Polymer Electrolyte Membrane Fuel Cell Based on Zirconium Phosphate and Phosphoric Acid. Electrochem. Solid State Lett. 2009, 12, 171-175. [CrossRef]

51. Ahmad, H.; Kamarudin, S.K.; Hasran, U.A.; Daud, W.R.W. A novel hybrid Nafion-PBI-ZP membrane for direct methanol fuel cells. Int. J. Hydrogen Energy 2011, 36, 14668-14677. [CrossRef] 